\title{
THE EFFECTS OF DPP4 INHIBITORS ON LIPID STATUS AND BLOOD PRESSURE IN RATS WITH DIABETES MELLITUS TYPE 2
}

Stefani Bolevich ${ }^{1}$, Nevena Draginic ${ }^{2}$, Marijana Andjic ${ }^{2}$, Nevena Jeremic ${ }^{2}$, Sergey Bolevich ${ }^{3}$, Petr F Litvitskiy ${ }^{1}$ and Vladimir Jakovljevic ${ }^{3,4}$

${ }^{1} 1$ st Moscow State Medical University I.M. Sechenov, Department of Pathophysiology, Moscow, Russian Federation ${ }^{2}$ University of Kragujevac, Faculty of Medical Sciences, Department of Pharmacy, Kragujevac, Serbia

${ }^{3} 1$ st Moscow State Medical University I.M. Sechenov, Department of Human Pathology, Moscow, Russian Federation

${ }^{4}$ University of Kragujevac, Faculty of Medical Sciences, Department of Physiology, Kragujevac, Serbia

\section{EFEKTI INHIBITORA DPP4 NA LIPIDNI STATUS I KRVNI PRITISAK PACOVA OBOLELIH OD DIABETES MELLITUS-A TIP 2}

Stefani Bolevich ${ }^{1}$, Nevena Draginić ${ }^{2}$, Marijana Anđić ${ }^{2}$, Nevena Jeremić², Sergey Bolevich ${ }^{3}$, Petr F Litvitskiy ${ }^{1}$ i Vladimir Jakovljević3,4

${ }^{1}$ Prvi moskovski državni medicinski univerzitet I.M. Sechenov, Katedra za patofiziologiju, Moskva, Ruska Federacija

${ }^{2}$ Univerzitet u Kragujevcu, Fakultet medicinskih nauka, Katedra za farmaciju, Kragujevac, Srbija

${ }^{3}$ Prvi moskovski državni medicinski univerzitet I.M. Sechenov, Katedra za humanu patologiju, Moskva, Ruska Federacija

${ }^{4}$ Univerzitet u Kragujevcu, Fakultet medicinskih nauka, Katedra za fiziologiju, Kragujevac, Srbija

\begin{abstract}
The aim of the present study was to examine, evaluate and compare the effects of administered dipeptidyl peptidase-4(DPP4) inhibitors saxagliptin and sitagliptin on lipid status parameters and blood pressure in rats with streptozotocine induced diabetes mellitus type 2. Forty-eight Wistar albino rats were divided randomly into 4 groups: 1. group I: control healthy group; 2. group II: rats with diabetes mellitus type 2; 3. group III: rats with diabetes mellitus type $2+$ treated with $0.6 \mathrm{mg} / \mathrm{kg}$ of sitagliptin; 4. group IV: rats with diabetes mellitus type 2 treated with $0.45 \mathrm{mg} / \mathrm{kg}$ of saxagliptin. The rats from experimental groups were fed with a high-fat diet for 4 weeks and after 6-8 h of starvation received one dose of streptozotocin (STZ) intraperitoneally (25 mg/kg body weight) to induce type 2 diabetes mellitus (T2DM). Animals with fasting glucose above $7 \mathrm{mmol} / \mathrm{L}$ and insulin over $6 \mathrm{mmol} / \mathrm{L}$ were included in the study as rats with T2DM. Upon completion of the experiments, the blood was collected from the anesthetized animals and serum triglyceride (TG), total cholesterol (TCH), high density lipoprotein $(H D L)$, and low density lipoprotein ( $L D L)$ were measured using spectrophotometry and commercial kits. At the beginning of the study and the day before sacrificing animals, the blood pressure and heart rate were measured by a tail-cuff noninvasive method. DPP4 inhibitors, as glucagon-like peptide-1 (GLP-1) agonists, were associated with modest reductions in $D B P, L D L-C, T C H$, and TGL and significant improvement in HDL, SBP and HR.
\end{abstract}

Keywords: DPP4 inhibitors, lipid status, blood pressure, diabetes mellitus type 2, rats.

\section{SAŽETAK}

Cilj ove studije je bio da ispita, proceni i uporedi efekte administriranih dipeptidil peptidaza-4 (DPP4) inhibitora saksagliptina $i$ sitagliptina na parametre lipidnog statusa i krvnog pritiska kod pacova sa dijabetes mellitusom tipa 2 izazvanim streptozotocinom. Čtrdeset osam Wistar albino pacova je svrstano u 4 grupe: 1. grupa I: kontrolna grupa zdravih pacova; 2. grupa II: pacovi sa diabetes mellitus tipom 2; 3. grupa III: pacovi sa diabetes mellitus tipom 2 tretirani sa 0,6 mg/kg sitagliptina; 4. grupa IV: pacovi sa diabetes mellitus tipom 2 tretirani sa $0.45 \mathrm{mg} / \mathrm{kg}$ saksagliptina. Pacovi iz eksperimentalnih grupa su hranjeni hranom sa visokim sadržajem masti 4 nedelje i nakon 6-8 sati gladovanja primili su jednu dozu streptozotocina (STZ) intraperitonealno $(25 \mathrm{mg} / \mathrm{kg}$ telesne težine) radi izazivanja dijabetes melitusa tipa 2 (T2DM). Životinje sa glukozom natašte iznad $7 \mathrm{mmol} / \mathrm{L}$ i insulinom preko 6 mmol/L uključene su u studiju kao pacovi sa T2DM. Po završetku eksperimentalnog perioda, krv je sakupljena od anesteziranih životinja i serumski trigliceridi (TG), ukupni holesterol (TCH), lipoproteini visoke gustine (HDL) i lipoproteini niske gustine (LDL) su određivani spektrofotometrijski i korišćenjem komercijalnih kitova. Na početku studije i dan pre žrtvovanja životinja, krvni pritisak i srčana frekvenca su mereni neinvazivnom metodom repne pletizmografije. Inhibitori DPP4, kao agonisti glucagonu-sličnog peptida-1 (GLP-1), bili su povezani sa blagim redukcijama DBP, LDL-C, TCH i TGL i pozitivno su uticali na HDL, SBP i HR.

Ključne reči: DPP4 inhibitori, lipidni status, krvni pritisak, diabetes melitus tip 2, pacovi. 


\section{INTRODUCTION}

Cardiovascular diseases, such as coronary heart disease, cerebrovascular disease, and peripheral artery disease have remained the leading cause of morbidity and mortality worldwide. Across Europe and the USA, myocardial infarction represents direct cause of death in $40-50 \%$ of patients with diabetes, and the number of patients with diabetes that die as a direct result of ischemic heart disease is reported to be increasing (1). It is well known and explained that existing atherosclerotic vascular lesions and diabetes mellitus are with no doubt the strongest risk factors for further life-threatening vascular diseases. Hyperlipidemia and diabetes mellitus increase cardiovascular events via increasing atherosclerosis. What is more, collateral artery growth (arteriogenesis), which function is to compensate the loss of an artery due to atherosclerosis, is compromised in diabetes mellitus, a disease which is almost always associated with dyslipidemia (2). According to novel investigation, there is a high need for effective drugs that show positive effects in patients with diabetes, even with insulin resistance, but also express cardioprotective effects and therefore postpone or decrease the risk of cardiovascular complications in diabetic patients. Particularly, these drugs should have the capacity to promote arteriogenesis, which is a tissue-, and even life-saving, process. Dipeptidyl-peptidase 4 (DPP4/CD26) inhibitors might present such drugs.

Dipeptidyl peptidase-4 (DPP4) is a widely expressed protease that cleaves the $\mathrm{N}$-terminal of peptides containing a penultimate alanine or proline, such as the incretins, glucagonlike peptide-1 (GLP-1), and glucose-dependent insulinotropic polypeptide (or gastric inhibitory polypeptide GIP) (1). Drugs that inhibit DPP4 exhibit a decrease in degradation of these hormones, which improves glycemic control through increased glucose-mediated insulin secretion, decreased glucagon release and delayed gastric emptying. These hypoglycemic drugs of newer generation have shown to be effective, well tolerated and therefore, increasingly prescribed. In addition, recent research put the focus on potential cardioprotective and antihyperlipidemic effects of these drugs, beyond glycemic control, thus, making them an interesting and attractive therapeutic strategy, alone or in combination with other hypoglycemic drugs $(2,3)$. Not all representatives of this group of drugs express the same pharmacodynamics. For example, in vitro study has shown stronger inhibition of DPP4 and slower rate of dissociation from its active site of saxagliptine in comparison with sitagliptin and vildagliptin (4).

Besides outstanding glucose-lowering effects, DPP4 inhibitors have also shown other beneficial effects that are not of metabolic nature. This refers to anti-inflammatory effect and cardioprotective effect especially via blood pressure (BP) regulation. Recent findings suggest that sitagliptin could decrease systolic blood pressure (SBP), independently of glucoselowering effect (5). Additionally, it was shown that sitagliptin exerts BP reduction effect both in diabetic and non-diabetic patients (6-9). Data provided from other studies have also confirmed hypotensive effects of DPP-4 inhibitors in animal models and supported this phenomenon (10-13). On the other hand, there is a growing number of evidence claiming the opposite - that no changes in $\mathrm{BP}$ were measured when compared to control group (14-17). Furthermore, some research groups have come to conclusion that DPP-4 inhibitors might even lead to the increase in BP when combined with ACE (angiotensin-converting enzyme) inhibitors (18).

Taken into consideration all mentioned above, the aim of the present study was to examine, evaluate and compare the effects of administered DPP4 inhibitors saxagliptin and sitagliptin on lipid status parameters and blood pressure in rats with streptozotocine induced diabetes mellitus type 2 .

\section{MATERIALS AND METHODS}

\section{Ethical approval}

This research was carried out in the laboratory for cardiovascular physiology of the Faculty of Medical Sciences, University of Kragujevac, Serbia. The protocol of the current study was approved by the Ethical Committee for the experimental animals' well-being of the Faculty of Medical Sciences, University of Kragujevac, Serbia. All experiments were performed according to EU Directive for welfare of laboratory animals (86/609/EEC) and principles of Good Laboratory Practice (GLP).

\section{Animals and design of the study}

Forty-eight Wistar albino rats (males, six weeks old, body weight $200 \pm 20 \mathrm{~g}$, at the beginning of experiments) were included in the study. They were housed in a room with a $12 / 12-$ hour light/dark cycle, an ambient temperature of $22 \pm 2{ }^{\circ} \mathrm{C}$. The rats had free access to food and water - ad libitum. Rats were divided randomly into 4 groups (12 animals per group):

1. Group I: Control healthy group $(n=12)$;

2. Group II: Rats with diabetes mellitus type $2(n=12)$;

3. Group III: Rats with diabetes mellitus type 2 treated with $0.6 \mathrm{mg} / \mathrm{kg}$ of sitagliptin $(\mathrm{n}=12)$;

4. Group IV: Rats with diabetes mellitus type 2 treated with $0.45 \mathrm{mg} / \mathrm{kg}$ of saxagliptin $(\mathrm{n}=12)$.

Except for the control healthy group, the rats were fed with a high-fat diet for 4 weeks and after $6-8$ h of starvation received one dose of STZ intraperitoneally to induce T2DM. STZ was prepared ex tempore by dissolving in citrate buffer and, depending on the body weight, it was administered in a dose of $25 \mathrm{mg} / \mathrm{kg}$ (18). Three days after STZ injection and 12 $\mathrm{h}$ after starvation fasting glucose and insulin level as well as blood pressure were measured. Animals with fasting glucose level above $7 \mathrm{mmol} / \mathrm{L}$ and insulin level over $6 \mathrm{mmol} / \mathrm{L}$ were included in the study and were used in the study as rats with T2DM. The T2DM rats were then randomly divided into three groups: T2DM rats $(n=12)$, T2DM rats treated with 0.6 $\mathrm{mg} / \mathrm{kg}$ body weight of sitagliptin $(\mathrm{n}=12)$ and T2DM treated with $0.45 \mathrm{mg} / \mathrm{kg}$ body weight of saxagliptin ( $\mathrm{n}=12)$. Sitagliptin and saxagliptin were applied intraperitoneally once a day for three weeks. 


\section{Drugs}

Streptozotocin (MW= 265,221), sitagliptin (MW= 523,32) and saxagliptin (MW= 315,41) were purchased from SigmaAldrich Chemie GmbH Eschen str. 5, 82024 Taufkirchen, Germany.

\section{Evaluation of blood pressure and heart rate}

At the beginning of the study and the day before sacrificing animals, the blood pressure and heart rate were measured by a tail-cuff noninvasive method BP system (Rat Tail Cuff Method Blood Pressure Systems (MRBP-R), IITC Life Science Inc., Los Angeles, CA, USA) (19). At least ten determinations were made in each session, with mean values taken.

\section{Lipid profile}

Upon completion of the experiments, the blood was collected from the anesthetized animals into blood collection tubes after an overnight fast (12 h). After standing for $30 \mathrm{~min}$, the serum was prepared by centrifugation of blood at $1000 \times \mathrm{g}$ for $10 \mathrm{~min}$ at $4^{\circ} \mathrm{C}$ and stored at $-80^{\circ} \mathrm{C}$ until analysis.
Serum triglyceride (TG), total cholesterol (TCH), high density lipoprotein (HDL), low density lipoprotein (LDL) were measured in the serum using spectrophotometry and commercial kits from Siemens Healthcare Diagnostics (Frimley, Camberley, Surrey, UK) and according to the manufacturer's instructions on the programmed analisator (Dimension Xpand, Siemens, IL, USA).

\section{Statistical analysis}

We used traditional parameters of descriptive statistics: average value \pm standard deviation (SD), and minimal and maximal values. Normality of the parameter distribution was evaluated with the Shapiro-Wilk and Kolmogorov-Smirnov tests. Additionally, data was analyzed using a one-way analysis of variance (ANOVA) and the post hoc Bonferroni test for multiple comparisons. The statistical significance was based on $\mathrm{p}<0.05$. Complete statistical evaluation was performed with SPSS Statistics 22 (SPSS, Chicago, IL).

\section{RESULTS}

\section{Lipid profile}

Level of triglycerides (TGL), total cholesterol (TCH) and low-density lipoprotein (LDL) were significantly increased in experimental groups (rats with T2DM) compared to the control group, while the level of high-density lipoprotein (HDL) was decreased. Sitagliptin and saxagliptin have significantly decreased the level of TGL, TCH, and LDL compared to the T2DM group. There was no significant change in the level of HDL (Figure 1).

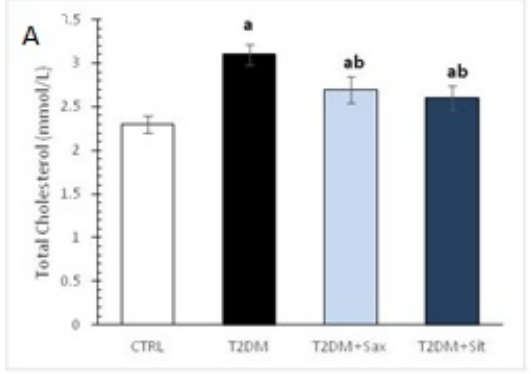

B
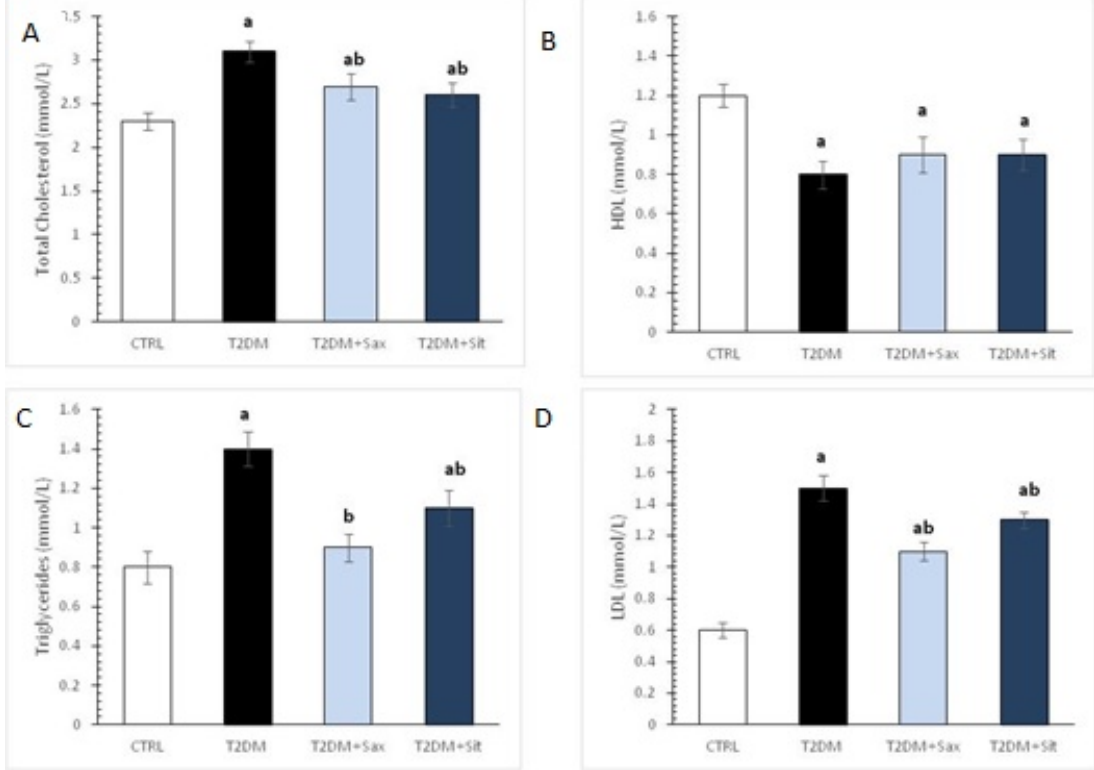

D



Figure 1: Changes in lipid profile in healthy and rats with T2DM:

(A) Total Cholesterol (TCL, mmol/l); (B) high-density lipoprotein (HDL, mmol/l);

(C) Triglycerides (TGL, mmol/l); (D) Low-density lipoprotein (LDL, mmol/l). 
Values are expressed as mean \pm standard deviation (SD) for 12 animals, for each group. Values $\mathrm{p}<0.05$ were considered statistically significant. a - statistical significance in relation to control (CTRL) group; b - statistical significance in relation to T2DM group.
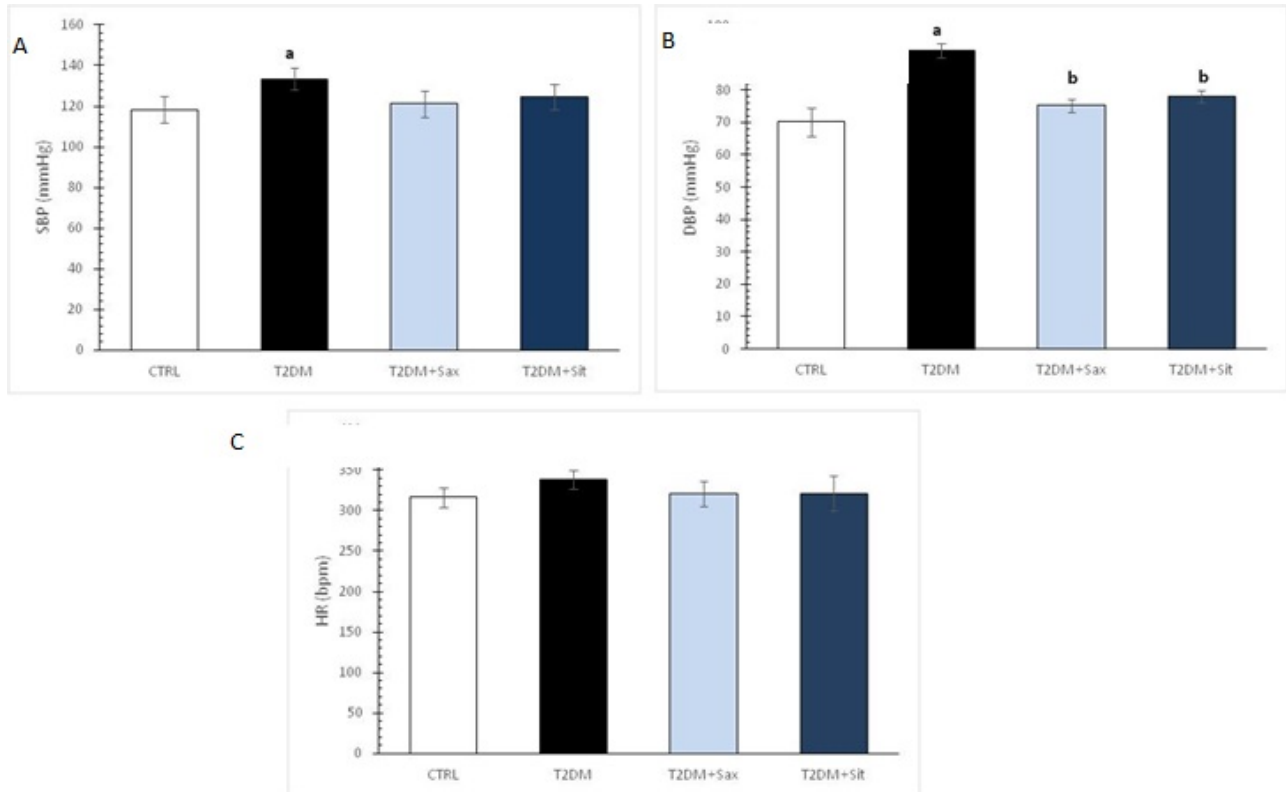

Figure 2: Changes in blood pressure and heart rate in healthy and rats with T2DM:

(A) systolic blood pressure (SBP, mmHg); (B) diastolic blood pressure (DBP, mmHg);

(C) heart rate (HR, bpm). Values are expressed as mean \pm standard deviation for 12 animals, for each group.

Values $p<0.05$ were considered statistically significant. a - statistical significance in relation to control (CTRL) group; b - statistical significance in relation to T2DM group.

\section{DISCUSSION}

The prevalence of hypertension in individuals with T2DM is estimated to be twice higher compared to non-diabetic individuals $(20,21)$. Possible reasons for this include diabetes related metabolic disorders, such as chronic hyperglycemia and hyperlipidemia along with low grade inflammation and oxidative stress. Blood pressure responses to DPP-4 inhibitor therapy are shown to be either neutral or modestly reduced (22-25). In addition, by measuring the blood pressure, we have confirmed the existence of a model diabetes mellitus type 2, which is quite obvious by noticing a statistically significant difference in the systolic and diastolic pressure in the T2DM group compared to the control. Using this parameter, we have managed to show that the drugs from the group of DPP-4 inhibitors lower diastolic blood pressure in comparison with T2DM group (Figure 2).

Recent studies highlighted that sitagliptin might induce changes in blood pressure in different ways, but this depends primarily on the presence of coronary disease, antihyperten-

\section{Blood pressure and heart rate}

Systolic and diastolic blood pressures were significantly increased in the T2DM group compared to the control group. Diastolic pressure was significantly decreased in groups with sitagliptin and saxagliptin compared to the T2DM group. There was no significant change in the heart rate (Figure 2). 
immune systems, both innate and adaptive might contribute to low-grade inflammation, which is connected with the development and progression of hypertension. DPP4 (CD26), besides being included in glucose and lipid metabolism, also participates in non-specific inflammation by regulating the activity and chemotaxis of macrophages, monocytes, NK and T cells. These cells secrete inflammatory mediators that can disturb the function of vascular endothelium (reactive oxygen species, cytokines, chemokines, adhesion molecules) in the form of increased proliferation of smooth muscle cells and vascular remodelling. Recent studies provided evidence about DPP4 inhibitors treatment inhibiting production of cytokines controlling the proliferation of $\mathrm{T}$ lymphocites and therefore express hypotensive effect via reduction of inflammation (28, $30,31)$. Other research groups claimed the opposite since no effect on BP was noticed with DPP4 inhibitors treatment. There is also smaller amount of evidence regarding possible increase in BP by using ACE inhibitors and DPP4 inhibitors co-therapy $(14,15,17)$. As for heart rate, values did not vary between groups and no statistically significant differences were noticed. DPP-4 inhibitors have not shown any effect on this parameter in our research (Figure 2). These results are consistent with various studies, where the DPP4 inhibitors therapy did not ameliorate cardiovascular outcomes in T2DM patients.

Lipid profile is a strong determinant of cardiovascular risk in T2DM. Current guidelines recommend an accurate control of hypercholesterolemia in order to reduce macrovascular complications. The fact that type 2 diabetic patients are more likely to be dyslipidemic than the general population is well known for decades. Lipid abnormalities associated with T2DM refer to high serum triglyceride levels, a high proportion of small dense low-density lipoprotein (LDL) particles, higher triglyceride-enriched, verylow-density lipoprotein (VLDL) particles, and lower protective high-density lipoprotein cholesterol (HDL) levels, together with glycation of apolipoproteins and increased LDL oxidation, all of which contribute to genesis of foam cell in atherosclerosis $(32,33)$. According to Derosa et al, the addition of sitagliptin to existing hypoglycemic therapy might lead to a better and durable (over 7 years of therapy) improvement of lipid profile. This beneficial effect is supposed to be due to delayed gastric emptying (34). Our study results elucidated that sitagliptin and saxagliptin improve lipid status in T2DM rats, via significant reduction of TCH, LDL and TGL (Figure 1). In line with these results are also the results of other research groups $(35,36)$. Possible explanation for beneficial lipid effects of DPP4 inhibitors may be connected to its stimulating effect on the activated proteine-kinase pathway, which leads to increase in glucose and lipid catabolism (37). On the other hand, no improvement in HDL parameters was achieved in our study, which is in correlation with the findings of Saad et al. (36). What is more, GIP can purify chylomicron in the circulation by stimulating the lipoproteine lipase from adipose tissue, while GLP-1 could decrease the postprandial secretion of triacylglycerol after meal (38-40). Since DPP inhibitors potentiate the GLP-1 and GIP function, it is clear why it improves lipid profile. Clinical trials have also confirmed beneficial effects of sitagliptin in diabetic patients, referring to amelioration of lipoprotein and lipid profile, which is explained by decrease in atherogenic remnant lipoproteins (RemL-C) (41).

\section{CONCLUSION}

DPP4 inhibitors, as GLP-1 agonists, were associated with modest reductions in DBP, LDL-C, TCH, and TGL and significant improvement in HDL, SBP and HR. These drugs might be helpful in achieving homeostasis in lipid status and blood pressure in T2DM patients. Hence, further evidence is needed to determine if improvements in lipid profile and BP might translate into reductions and amelioration of cardiovascular outcomes.

\section{REFERENCES}

1. World-Health-Organisation. Cardiovascular Diseases (cvds) World-Health-Organisation; Geneva, Switzerland: 2013.

2. Abaci A, Oguzhan A, Kahraman S, Eryol NK, Unal S, Arinc H, et al. Effect of diabetes mellitus on formation of coronary collateral vessels. Circulation 1999; 99: 2239-42.

3. Lambeir AM, Durinx C, Scharpé S, De Meester I. Dipeptidyl-peptidase IV from bench to bedside: an update on structural properties, functions, and clinical aspects of the enzyme DPP IV. Crit Rev Clin Lab Sci 2003; 40(3): 20994.

4. Zhong J, Rao X, Rajagopalan S. An emerging role of dipeptidyl peptidase 4 (DPP4) beyond glucose control: potential implications in cardiovascular disease. Atherosclerosis 2013; 226(2): 305-14.

5. Herman GA, Stein PP, Thornberry NA, Wagner JA. Dipeptidyl peptidase- 4 inhibitors for the treatment of type 2 diabetes: focus on sitagliptin. Clin Pharmacol Ther 2007; 81(5): 761-7.

6. Wang A, Dorso C, Kopcho L, Locke G, Langish R, Harstad E, et al. Potency, selectivity and prolonged binding of saxagliptin to DPP4: maintenance of DPP4 inhibition bysaxagliptin in vitro and ex vivo when compared to a rapidly-dissociating DPP4 inhibitor. BMC Pharmacol 2012; 12: 2.

7. Jianqiang Z, Qiuyue C, Jixin Z, Chaohong L, Bing Z, Quan G. DPP-4 Inhibitors as Potential Candidates for Antihypertensive Therapy: Improving Vascular Inflammation and Assisting the Action of Traditional Antihypertensive Drugs. Front Immunol 2019; 10: 1050.

8. Ogawa S, Ishiki M, Nako K, Okamura M, Senda M, Mori T, et al. . Sitagliptin, a dipeptidyl peptidase-4 inhibitor, decreases systolic blood pressure in Japanese hypertensive patients with type 2 diabetes. Tohoku J Exp Med 2011; 223: 133 .

9. Duvnjak L, Blaslov K. Dipeptidyl peptidase-4 inhibitors improve arterial stiffness, blood pressure, lipid profile and inflammation parameters in patients with type 2 diabetes mellitus. Diabetol Metab Syndr 2016; 8: 26.

10. Chen K, Zhuo T, Wang J, Mei Q. Saxagliptin upregulates nesfatin-1 secretion and ameliorates insulin resistance and 
metabolic profiles in type 2 diabetes mellitus. Metab Syndr Relat Disord 2018; 16: 336-41.

11. Hussain M, Atif MA, Ghafoor MB. Beneficial effects of sitagliptin and metformin in non-diabetic hypertensive and dyslipidemic patients. Pak J Pharm Sci 2016; 29: 2385-9.

12. Pacheco BP, Crajoinas RO, Couto GK, Davel AP, Lessa LM, Rossoni LV, et al. . Dipeptidyl peptidase IV inhibition attenuates blood pressure rising in young spontaneously hypertensive rats. J Hypertens 2011; 29: 520-8.

13. Liu L, Liu J, Wong WT, Tian XY, Lau CW, Wang YX, et al. Dipeptidyl peptidase 4 inhibitor sitagliptin protects endothelial function in hypertension through a glucagon-like peptide 1-dependent mechanism. Hypertension 2012; 60: 833-41.

14. Sufiun A, Rafiq K, Fujisawa Y, Rahman A, Mori H, Nakano D, et al. . Effect of dipeptidyl peptidase-4 inhibition on circadian blood pressure during the development of salt-dependent hypertension in rats. Hypertens Res 2015; 38: 237-43.

15. Mason RP, Jacob RF, Kubant R, Ciszewski A, Corbalan JJ, Malinski T. Dipeptidyl peptidase-4 inhibition with saxagliptin enhanced nitric oxide release and reduced blood pressure and sICAM-1 levels in hypertensive rats. J Cardiovasc Pharmacol 2012; 60: 467-73.

16. Alter ML, Ott IM, von Websky K, Tsuprykov O, Sharkovska Y, Krause-Relle K, et al. DPP-4 inhibition on top of angiotensin receptor blockade offers a new therapeutic approach for diabetic nephropathy. Kidney Blood Press Res 2012; 36: 119-30.

17. Chaykovska L, Alter ML, von Websky K, Hohmann M, Tsuprykov O, Reichetzeder C, et al. Effects of telmisartan and linagliptin when used in combination on blood pressure and oxidative stress in rats with 2-kidney-1-clip hypertension. J Hypertens 2013; 31: 2290-8.

18. Pari L, Chandramohan R. Modulatory effects of naringin on hepatic key enzymes of carbohydrate metabolism in high-fat diet/low-dose streptozotocin-induced diabetes in rats. Gen Physiol Biophys 2017; 36(3): 343-52.

19. Feng M, Whitesall S, Zhang Y, Beibel M, D'Alecy L, DiPetrillo K. Validation of volume-pressure recording tailcuff blood pressure measurements. Am J Hypertens 2008; 21(12):1288-91.

20. Jackson EK, Mi Z, Tofovic SP, Gillespie DG. Effect of dipeptidyl peptidase 4 inhibition on arterial blood pressure is context dependent. Hypertension 2015; 65: 238-49.

21. Lago RM, Singh PP, Nesto RW. Diabetes and hypertension. Nat Clin Pract Endocrinol Metab 2007; 3(10): 667.

22. Ogawa S, Ishiki M, Nako K, Okamura M, Senda M, Mori T, et al. Sitagliptin, a dipeptidyl peptidase-4 inhibitor, decreases systolic blood pressure in Japanese hypertensive patients with type 2 diabetes. Tohoku J Exp Med 2011; 223(2): 133-5.

23. Kubota Y, Miyamoto M, Takagi G, Ikeda T, KirinokiIchikawa S, Tanaka K et al. The Dipeptidyl Peptidase-4 Inhibitor Sitagliptin Improves Vascular Endothelial Function in Type 2 Diabetes. J Korean Med Sci 2012; 27(11): 1364-70.

24. Mistry GC, Maes AL, Lasseter KC, Davies MJ, Gottesdiener KM, Wagner JA, et al. Effect of sitagliptin, a dipeptidyl peptidase-4 inhibitor, on blood pressure in nondiabetic patients with mild to moderate hypertension. J Clin Pharmacol 2008; 48(5): 592-8.

25. Gouni-Berthold I, Hanssen R, Ravarani L, Berthold HK. Management of Blood Pressure and Heart Rate in Patients with Diabetes Mellitus. Curr Pharm Des 2017; 23(31): 4573-82.

26. Marney A, Kunchakarra S, Byrne L, Brown NJ. Interactive hemodynamic effects of dipeptidyl peptidase-IV inhibition and angiotensin-converting enzyme inhibition in humans. Hypertension 2010; 56: 728-33.

27. Monami M, Vitale V, Ambrosio VL, et al. Effects on lipid profile of dipeptidyl peptidase 4 inhibitors, pioglitazone, acarbose, and sulfonylureas: meta-analysis of placebocontrolled trials. Adv Ther 2012; 29(9): 736-46.

28. Nystrom T, Gonon AT, Sjoholm A, Pernow J. Glucagonlike peptide-1 relaxes rat conduit arteries via an endothelium-independent mechanism. Regul Pept 2005; 125: 1737.

29. Shah Z, Pineda C, Kampfrath T, Maiseyu A, Ying Z, Racoma I, et al. Acute DPP-4 inhibition modulates vacular tone through GLP-1 independent pathways. Vascular Pharmacol 2011; 55(1-3): 111-7.

30. da Silva Júnior WS, Souza M, Nogueira Neto JF, Bouskela E, Kraemer-Aguiar LG. Constitutive DPP4 activity, inflammation, and microvascular reactivity in subjects with excess body weight and without diabetes. Microvasc Res 2018; 120: 94-9.

31. Schon E, Demuth HU, Eichmann E, Horst HJ, Korner IJ, Kopp J, et al. Dipeptidyl peptidase IV in human T lymphocytes. Impaired induction of interleukin 2 and gamma interferon due to specific inhibition of dipeptidyl peptidase IV. Scand J Immunol 1989; 29: 127-32.

32. Avogaro A, Giorda C, Maggini M, et al. Incidence of coronary heart disease in type 2 diabetic men and women: impact of microvascular complications, treatment, and geographic location. Diabetes Care 2007; 30: 1241-7.

33. Gaede P, Lund-Andersen H, Parving HH, Pedersen O. Effect of a multifactorial intervention on mortality in type 2 diabetes. N Engl J Med 2008; 358: 580-91.

34. Derosa G, Tritto I, Romano D, D'Angelo A, Catena G, Maffioli P. Effects of Sitagliptin on Lipid Profile in Patients With Type 2 Diabetes Mellitus After 7 Years of Therapy. J Clin Pharmacol 2019 doi: 10.1002/jcph.1431. [Epub ahead of print].

35. Addison, D, and Aguilar, D. Diabetes and cardiovascular disease: the potential benefit of incretin-based therapies. Curr Atheroscler Rep 2011; 13(2): 115-22.

36. Saad, M.I., Kamel, M.A., and Hanafi, M.Y. Modulation of adipocytokines production and serum NEFA level by metformin, glimepiride, and sitagliptin in HFD/STZ diabetic rats. Biochem Res Int 2015: 138134.

37. Issa D, Patel V, Sanyal AJ. Future therapy for nonalcoholic fatty liver disease. Liver Int 2018; 38(1): 56-63.

38. Wasada T, McCorkle K, Harris V, Kawai K, Howard B, Unger RH. Effect of gastric inhibitory polypeptide on plasma levels of chylomicron triglycerides in dogs. J Clin Invest 1981; 68: 1106-7. 
39. Kim SJ, Nian C, McIntosh CH. Activation of lipoprotein lipase by glucose-dependent insulinotropic polypeptide in adipocytes. A role for a protein kinase B, LKB1, and AMP-activated protein kinase cascade. J Biol Chem 2007; 282: 8557-67.

40. Meier JJ, Gethmann A, Götze O, Gallwitz B, Holst JJ, Schmidt WE, et al. Glucagon-like peptide 1 abolishes the postprandial rise in triglyceride concentrations and lowers levels of non-esterified fatty acids in humans. Diabetologia 2006; 49: 452-8.

41. Masuda D, Kobayashi T, Sairyou M, Hanada H, Ohama T, Koseki M, et al. Effects of a Dipeptidyl Peptidase 4 Inhibitor Sitagliptin on Glycemic Control and Lipoprotein Metabolism in Patients with Type 2 Diabetes Mellitus (GLORIA Trial). J Atheroscler Thromb 2018; 25(6): 51220. 